\title{
Article \\ Dietary Isothiocyanates, Sulforaphane and 2-Phenethyl Isothiocyanate, Effectively Impair Vibrio cholerae Virulence
}

\author{
Klaudyna Krause ${ }^{1}$, Agnieszka Pyrczak-Felczykowska ${ }^{2}$, Monika Karczewska ${ }^{1}$, Magdalena Narajczyk ${ }^{3}{ }^{\circledR}$, \\ Anna Herman-Antosiewicz ${ }^{4}$, Agnieszka Szalewska-Pałasz ${ }^{1}$ (D) and Dariusz Nowicki ${ }^{1, *}$ (i) \\ 1 Department of Bacterial Molecular Genetics, Faculty of Biology, University of Gdansk, 80-308 Gdansk, \\ Poland; klaudyna.krause@phdstud.ug.edu.pl (K.K.); monika.szalkowska@phdstud.ug.edu.pl (M.K.); \\ agnieszka.szalewska-palasz@ug.edu.pl (A.S.-P.) \\ 2 Department of Physiology, Medical University of Gdansk, 80-211 Gdansk, Poland; \\ agnieszka.pyrczak-felczykowska@gumed.edu.pl \\ 3 Department of Electron Microscopy, Faculty of Biology, University of Gdansk, 80-308 Gdansk, Poland; \\ magdalena.narajczyk@biol.ug.edu.pl \\ 4 Department of Medical Biology and Genetics, Faculty of Biology, University of Gdansk, 80-308 Gdansk, \\ Poland; anna.herman-antosiewicz@ug.edu.pl \\ * Correspondence: dariusz.nowicki@ug.edu.pl; Tel.: +48-58-523-60-65
}

check for updates

Citation: Krause, K.;

Pyrczak-Felczykowska, A.; Karczewska, M.; Narajczyk, M.; Herman-Antosiewicz, A.; Szalewska-Pałasz, A.; Nowicki, D. Dietary Isothiocyanates,

Sulforaphane and 2-Phenethyl Isothiocyanate, Effectively Impair Vibrio cholerae Virulence. Int. J. Mol. Sci. 2021, 22, 10187. https://doi.org/ 10.3390/ijms221910187

Academic Editor: Carlos Juan Nicolau

Received: 29 July 2021

Accepted: 20 September 2021

Published: 22 September 2021

Publisher's Note: MDPI stays neutral with regard to jurisdictional claims in published maps and institutional affiliations.

Copyright: (c) 2021 by the authors. Licensee MDPI, Basel, Switzerland. This article is an open access article distributed under the terms and conditions of the Creative Commons Attribution (CC BY) license (https:/ / creativecommons.org/licenses/by/ $4.0 /)$.

\begin{abstract}
Vibrio cholerae represents a constant threat to public health, causing widespread infections, especially in developing countries with a significant number of fatalities and serious complications every year. The standard treatment by oral rehydration does not eliminate the source of infection, while increasing antibiotic resistance among pathogenic $V$. cholerae strains makes the therapy difficult. Thus, we assessed the antibacterial potential of plant-derived phytoncides, isothiocyanates (ITC), against $V$. cholerae $\mathrm{O} 365$ strain. Sulforaphane (SFN) and 2-phenethyl isothiocyanate (PEITC) ability to inhibit bacterial growth was assessed. Minimum inhibitory concentration (MIC) and minimum bactericidal concentration (MBC) values indicate that these compounds possess antibacterial activity and are also effective against cells growing in a biofilm. Tested ITC caused accumulation of stringent response alarmone, ppGpp, which indicates induction of the global stress response. It was accompanied by bacterial cytoplasm shrinkage, the inhibition of the DNA, and RNA synthesis as well as downregulation of the expression of virulence factors. Most importantly, ITC reduced the toxicity of $V$. cholerae in the in vitro assays (against Vero and HeLa cells) and in vivo, using Galleria mellonella larvae as an infection model. In conclusion, our data indicate that ITCs might be considered promising antibacterial agents in $V$. cholerae infections.
\end{abstract}

Keywords: Vibrio cholerae; cholera; sulforaphane; phenethyl isothiocyanate; (p)ppGpp; antimicrobial; mode of action; virulence; biofilm

\section{Introduction}

Cholera infection caused by the Gram-negative, aquatic bacterium Vibrio cholerae leads to severe dehydrating diarrhea [1]. The worldwide spread of $V$. cholerae has caused seven large pandemic events in recorded history and remains a serious threat to public health in developing countries [2,3]. Approximately 2 to 9 million cases of cholera occur annually, resulting in near 100,000 deaths [4]. The case-fatality ratio is correlated mainly with proper and rapid treatment, ranging from $15.8 \%$ to less than $1 \%$, according to WHO statistics. Currently, the antibiotic resistance among $V$. cholerae strains is increasingly reported and threatens our ability to treat infected patients-which has created a major challenge to the development of an efficient therapy [5-7]. Oral rehydration treatment (ORT) is still the first-choice therapy for infected patients [8]. In more serious cases, intravenous rehydration and antibiotics are employed to reduce severe complication development. However, the ORT helps only to reduce symptoms of infection instead of actual treatment and cannot 
eliminate the cause of dysentery, while the continuous use of antibiotics contributes to a rapid emergence of antibiotic-resistant strains.

Cholera toxin (CT) and the toxin coregulated pilus (TCP) are two major virulence factors responsible for toxigenic abilities and intestinal colonization, respectively. Toxigenic abilities of $V$. cholerae are a consequence of $C T$ synthesis encoded by the ctx $A B$ gene, located on the CTX prophage integrated on the main chromosome. This has prompted many researchers to investigate the therapeutic potentials of traditional foods and beverages as well as natural products to inhibit the growth of $V$. cholerae or secretion of CT [5,9]. Moreover, virulence factors are regulated at the transcriptional level by a coordinated network of proteins that respond to specific environmental signals. Among these proteins is ToxT, an AraC family regulator that binds the promoters $t c p A$ and $c t x$ and directly activates virulence gene expression [1]. ToxT plays an essential role in $V$. cholerae virulence, and its expression and activity are highly regulated among epidemic $V$. cholerae strains.

$V$. cholerae strains are a common bacterial flora found in their natural reservoirs, both in freshwater and marine environments [10]. In these conditions, V. cholerae is mainly attached to the biotic surfaces, including those of aquatic species such as plankton, clams, crustaceans, plants, and insects $[10,11]$. The efficient propagation and resistance of bacterial cells in a nutritionally poor aquatic environment is facilitated by biofilm formation. It is assumed that the bacteria existing in the biofilm show a reduced sensitivity to environmental stresses, including digestion in the gastrointestinal tract, which is a route of infection; thus, the ability to form and maintain a biofilm is of serious clinical importance. Growth in biofilm induces a hyper-infectious phenotype in V. cholerae [12]; hence this feature and generally the higher number of bacteria in biofilm play a key role in transmission $[13,14]$. The hyperinfective state refers to a decrease in the number of cells required to cause disease. Thus, biofilm prevention and eradication are crucial steps in an anti-cholerae strategy. In an ongoing challenging era where microbial resistance to antibiotics is a significant problem in controlling infections caused by bacteria and in the occurrence of recurrent epidemics due to drug-resistant microorganisms, the development of new therapeutic strategies is of high priority. Targeting the regulation of bacterial virulence is considered one of the promising approaches [14,15].

Current antimicrobials in their mode of action target a relatively small number of essential cell functions such as DNA/RNA, cell wall, or protein synthesis. So, if these global process inhibitors are no longer effective, extensive efforts should be undertaken to investigate new and more specific targets. Phytoncides are a wide group of plant secondary metabolites which are a source of compounds with biological activities, including antimicrobial action. Among them, isothiocyanates (ITC), produced by Brassicaceae plants, have been shown to be effective against pathogenic bacteria and fungi $[16,17]$. Sulforaphane (SFN) is an aliphatic ITC available in the daily diet and abundant in the seeds and sprouts of cruciferous plants, such as broccoli [18]. 2-Phenethyl isothiocyanate (PEITC) is an aromatic member of ITC compounds, naturally occurring in watercress [19]. ITC compounds demonstrate numerous health benefits for humans, including anticancer, anti-inflammatory, and antioxidant properties [20]. Moreover, SFN and PEITC exhibit antimicrobial potential across Gram- and Gram+ bacterial pathogens like Enterococcus faecalis, Staphylococcus aureus, Campylobacter jejuni, or enteropathogenic Escherichia coli $[16,21]$. The mechanism of antibacterial action might vary in different bacterial species and includes cell membrane disruption, induction of general stress, and changing metabolism through stringent control activation [22-24]. In fact, it was demonstrated by us that the ITC-induced accumulation of the stringent response alarmones, ppGpp and pppGpp, underlies the antibacterial effect of ITC in bacterial pathogens $[21,22,25]$. The need for safe and effective compounds as therapeutic agents against drug-resistant microorganisms has driven many studies toward medicinal plants to date. The aim of this study was to comprehensively elucidate the antimicrobial effect of the food-grade natural compounds, SFN and PEITC, against the classical O1 biotype of $V$. cholerae O395 with a particular focus on their impact on virulence factors expression and biofilm control. Furthermore, we proposed an insight 
into their mode of action through activation of the bacterial stress response system-the stringent response. The effectiveness of SFN as a therapeutic agent was also examined in the G. mellonella infection model.

\section{Results and Discussion}

2.1. Sulforaphane and 2-Phenethyl Isothiocyanate Impair the Growth of V. cholerae in a Dose-Dependent Manner

The number of newly discovered or designed antimicrobials in recent years is dramatically low and even decreasing further. Thus, it can be expected that the imbalance between rising antimicrobial resistance among bacterial pathogens and the availability of treatment strategies will expand continuously [26,27]. Therefore, in this study, we decided to employ two members of ITC group, naturally occurring in Brassicaceae plants, SFN and PEITC, to test their antibacterial potency against $V$. cholerae. So far, their antimicrobial effect was demonstrated for such bacterial pathogens as E. coli, E. faecalis, S. aureus, Salmonella Montevideo, and C. jejuni $[21,24]$. Hence, we assessed the antimicrobial activity of ITC by microdilution sensitivity assay to obtain the inhibitory concentration values for the tested compounds. As shown in Figure 1a, the minimal inhibitory concentrations (MIC) of SFN and PEITC were $0.5 \mathrm{mM}$ and $2 \mathrm{mM}$, respectively, while their bactericidal potency was disclosed at $4 \mathrm{mM}$ and $10 \mathrm{mM}$ (SFN and PEITC, respectively). Chloramphenicol was used as a positive growth inhibition control in this study, and its MIC was assessed as $4 \mu \mathrm{g} / \mathrm{mL}$ and the MBC was $8 \mu \mathrm{g} / \mathrm{mL}$. These results were confirmed by the disc diffusion assay where SFN and PEITC were used in the concentrations of $30 \mu \mathrm{g} /$ disk resulting in a $23 \pm 2$ and $13 \pm 1 \mathrm{~mm}$ diameter zone of inhibition. This is consistent with results observed for chloramphenicol ( $30 \mu \mathrm{g} /$ disk) expressed as $21 \pm 2 \mathrm{~mm}$ diameter zone of inhibition. Next, we tested the assessed MIC and their fractions (1/2 to $1 / 16 \mathrm{MIC})$ to elucidate whether their action is dose-dependent. For this, the fresh cultures (optical density, $\mathrm{OD}_{600}=0.1$ ) were treated with SFN or PEITC in a range of concentrations, and the growth was monitored spectrophotometrically during $3 \mathrm{~h}$ and compared to untreated control (Figure $1 b, d$ ). This experiment showed that the statistically significant growth impairment was observed for concentrations even lower than MIC, namely $\frac{1}{2}$ and $\frac{1}{4}$ MIC (for SFN and PEITC, respectively) effectively inhibited the growth of bacterial cultures in their log-phase. The antimicrobial action of ITC differs among bacterial species tested to date $[21,24]$ and still remains poorly understood in terms of the molecular targets which decide about nature of their bacteriostatic and bactericidal action. However, as it has been previously reported, the bactericidal activity of aromatic glucosinolate-derived compounds, such as 2-phenylethyl and benzyl isothiocyanates, was higher in comparison with aliphatic glucosinolate derivatives, such as SFN, allyl-3-butenyl, and 4-pentenyl isothiocyanates [28].

Similarly, the bactericidal effect of isothiocyanates derived from aromatic glucosinolates was more pronounced than the activity of those derived from aliphatic precursors $[25,29]$. One of the proposed explanations of this phenomenon is the activation of oxidative stress response and subsequent changes in cellular redox homeostasis. It might be caused by interaction between isothiocyanates and thiol groups of microbial proteins engaged in redox homeostasis, such as glutathione [30]. Moreover, it was proposed that aromatic glucosinolate-derived isothiocyanates had higher reactivity through their ability to act as electron donors from a benzene ring [31,32]. However, our examination of the level of reactive oxygen species (ROS) in V. cholerae treated with SFN or PEITC in the 2,7-dichlorofluorescein diacetate (DCFH-DA) assay did not show a significant elevation of oxidative stress (data not shown), which is in agreement with our previous analyzes performed using the E. coli strain [25]. As the ROS level correlates with the mode of action of antimicrobials; therefore, the death curve upon ITC action was further analyzed (Figure 1c,e) to determine bacteriostatic/bactericidal activity against $V$. cholerae. The ITC was added to fresh culture adjusted to $\sim 10^{7}$ c.f.u $/ \mathrm{mL}$, then samples were collected, and viable cells were enumerated at indicated time points up to $24 \mathrm{~h}$. The results of this assay led us to the conclusion that antimicrobial action of both ITCs (in a range of concentrations from MIC to $5 \times$ MIC) is bacteriostatic as observed c.f.u. could not drop below the starting 
culture yield by $99.9 \%\left(\geq 3 \log _{10}\right)$, which is an arbitrary threshold for bactericides. Just a relatively high concentration of PEITC $(10 \times$ MIC) showed the bactericidal effect, but it could be difficult to consider it for in vivo use due to its cytotoxic effect. However, to date, bacteriostatic agents such as doxycycline, macrolides, or azithromycin are in routine use and recommended in cholera infection treatment (WHO).

a

$\begin{array}{lccc} & \begin{array}{c}\text { MIC } \\ \mathrm{mg} / \mathrm{ml}(\mathrm{mM})\end{array} & \begin{array}{c}\text { MBC } \\ \mathrm{mg} / \mathrm{ml}(\mathrm{mM})\end{array} & \begin{array}{c}\text { ZI } \\ \mathrm{mm}\end{array} \\ \text { PEITC } & 0.33(2.0) & 1.63(10) & 13 \pm 1 \\ \text { SFN } & 0.09(0.5) & 0.35(4) & 23 \pm 2\end{array}$
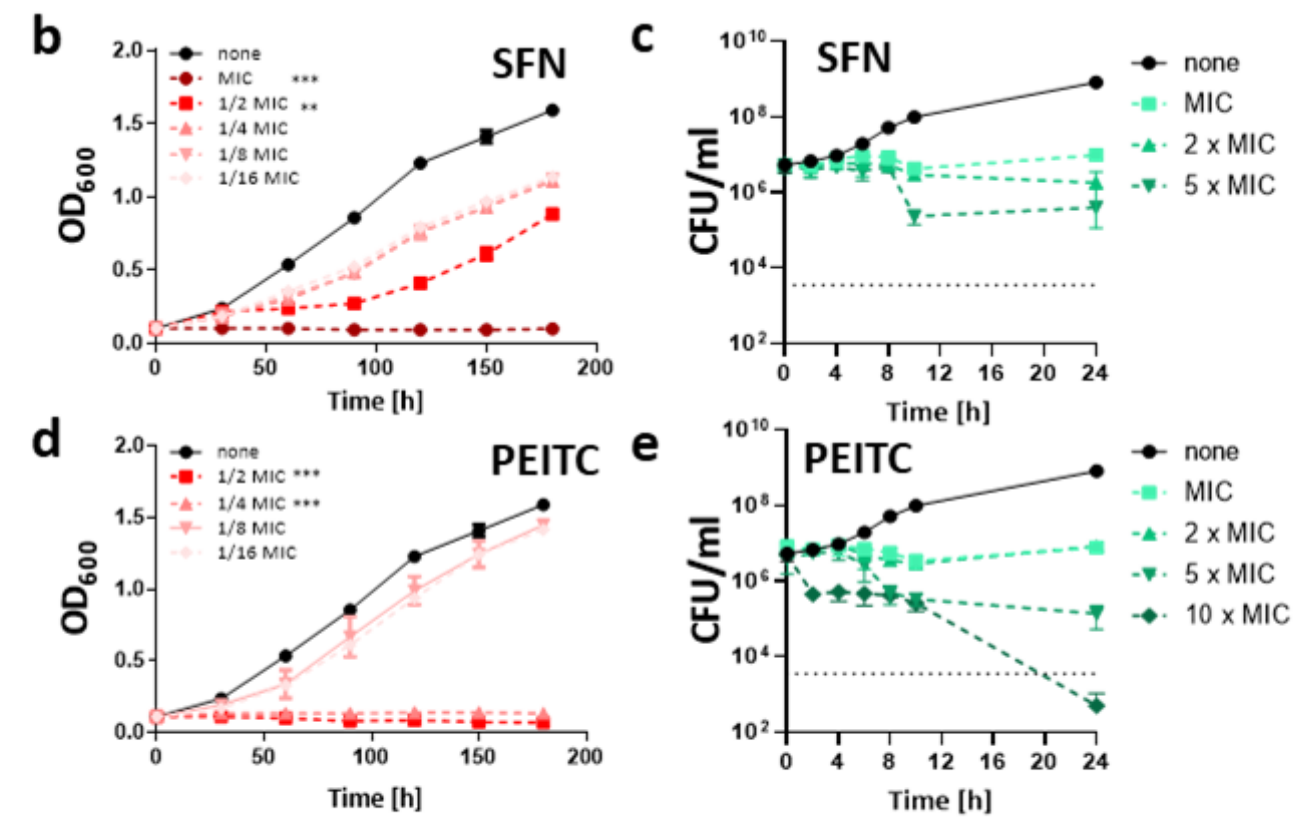

f

g
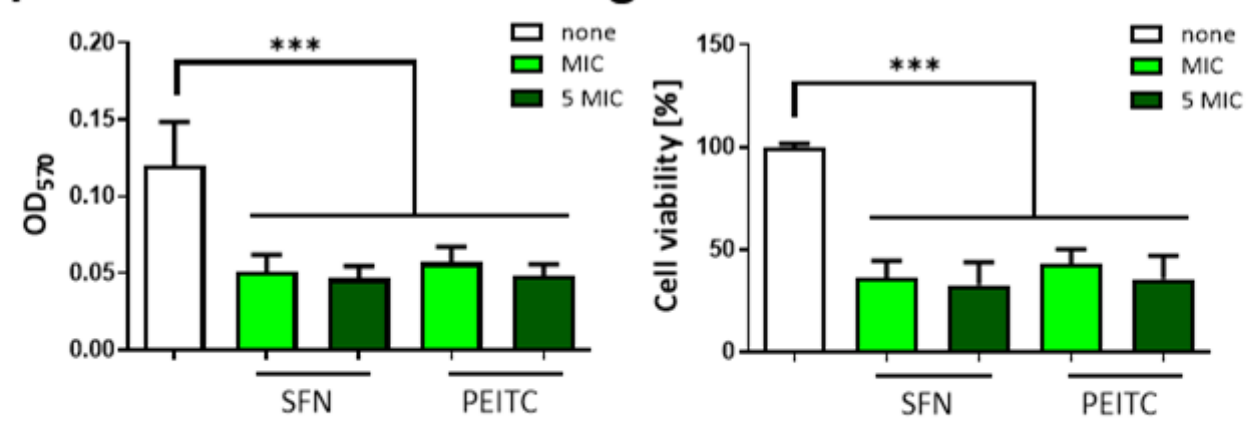

Figure 1. Antimicrobial activity of PEITC and SFN against $V$. cholerae. The $V$. cholerae susceptibility tests evaluated as minimal inhibitory (MIC) and bactericidal (MBC) concentration and zone inhibition assays. (a) The growth inhibition of $V$. cholerae treated with various concentrations of SFN (b) and PEITC (d). The killing curves of bacteria treated with SFN (c) and PEITC (e) in doses equal or greater than MIC. The results presented are mean values from 3 independent experiments with SD indicated. The reduction/inactivation of formed biofilm was assessed by crystal violet staining (f) and MTT assay $(\mathrm{g})$. The significance of differences between treated samples and the controls was tested using the Student's $t$-test. Statistical significance is marked with asterisks: ${ }^{* * *} p<0.001 ;{ }^{* *} p<0.01$.

The biofilm formation of $V$. cholerae plays a very important role in the survival of bacteria and their resistance to antimicrobials, as well as virulence level; thus, controlling biofilm by antimicrobial compounds is of crucial importance to prevent and combat infections. 
Therefore, the ability of ITC to affect biofilm was assessed in this study. Biofilms already formed by $V$. cholerae were exposed to the 1 or $5 \times$ MIC of SFN or PEITC and the biofilm mass was assessed by crystal violet staining (Figure 1f). Both tested ITCs reduced the biofilm significantly, and the effectiveness of this action was already exhibited for $1 \times$ MIC. In line with this observation, the viability of the biofilm-forming bacteria was also considerably reduced, as shown in the MTT assay (Figure 1g). Importantly, these effects were similar for PEITC and SFN. The ITCs were also tested for their ability to prevent biofilm formation. For this, compounds were added to the bacteria before the biofilm could be formed. This experiment showed that ITC can also reduce the transition of bacteria from sessile to biofilm state (Figure S1). SFN exhibited a stronger effect in this assay; however, PEITC at concentrations of 1 and $5 \times$ MIC also affected biofilm formation. To date, the antibiofilm activity of ITC has been scarcely described in the literature, with some exceptions [33-35]; therefore, the molecular basis of its nature is poorly understood. Kaiser et al. [23] showed that PEITC is effective in inhibiting $P$. aeruginosa biofilm formation even in concentrations significantly lower than the MIC $(\leq 29 \mathrm{mg} / \mathrm{mL})$. The authors indicated a good ability of the tested compound to penetrate the complexed biofilm matrix. In another study [36] iberin, ITC from horseradish, was proposed as a quorum sensing (QS) modulator that specifically blocked expression of QS-regulated genes in P. aeruginosa. These observations indicate that ITC can be used not only to inhibit bacterial exponential growth but, more importantly, also to diminish their biofilm formation and eradicate already formed biofilms, which highlights the important preventive role of ITC against pathologies induced by $V$. cholerae. Moreover, except for water contamination, seafood is most commonly associated with cholera [37]. ITCs are considered effective natural food preservatives. Allyl isothiocyanate in vapor and liquid forms has demonstrated high bactericidal activity against various food spoilage microorganisms [38]. Among others, its effectiveness in the preservation of fish products was shown. In this light, our findings could be useful in limiting the risk of cholera as a foodborne illness.

\subsection{ITC Affects the Cell Morphology of V. cholerae}

The observed growth inhibition and bacteriostatic action during ITC treatment were further analyzed by TEM observation to reveal their impact on the bacterial surface and morphological changes. It has been reported by others that ITC antimicrobial action can affect the function of the bacterial membranes and lead to their increased permeability or leakages (for review [24]). We showed that SFN and PEITC treatment (at their MICs) of $V$. cholerae led to cell shrinkage and cytoplasm condensation as indicated in photographs (Figure 2). Moreover, 120 min of ITC treatment resulted in cytosol leakage on distal parts of cells. However, the extensive damage of membranes or the cell wall was not observed. Thus, we can assume that the cell envelope is not a primary target of the tested compounds. Saleh et al. [39] reported that ITC-rich Moringa peregrina seed aqueous extract in a time-dependent manner affected the morphology of Salmonella enterica with progressive structural disorganization of the cytoplasm and the appearance of wavy membranes. In another study, Borges et al. [31] showed that aliphatic allyl-ITC (AITC) and PEITC were able to affect E. coli CECT 434 cell membrane integrity in a dose-dependent manner. The authors assumed that AITC and PEITC increased the hydrophilic character of the membrane, changing its physicochemical characteristics. However, it cannot be excluded that prolonged ITC treatment impacts cell morphology which is a secondary effect of these antimicrobials. 


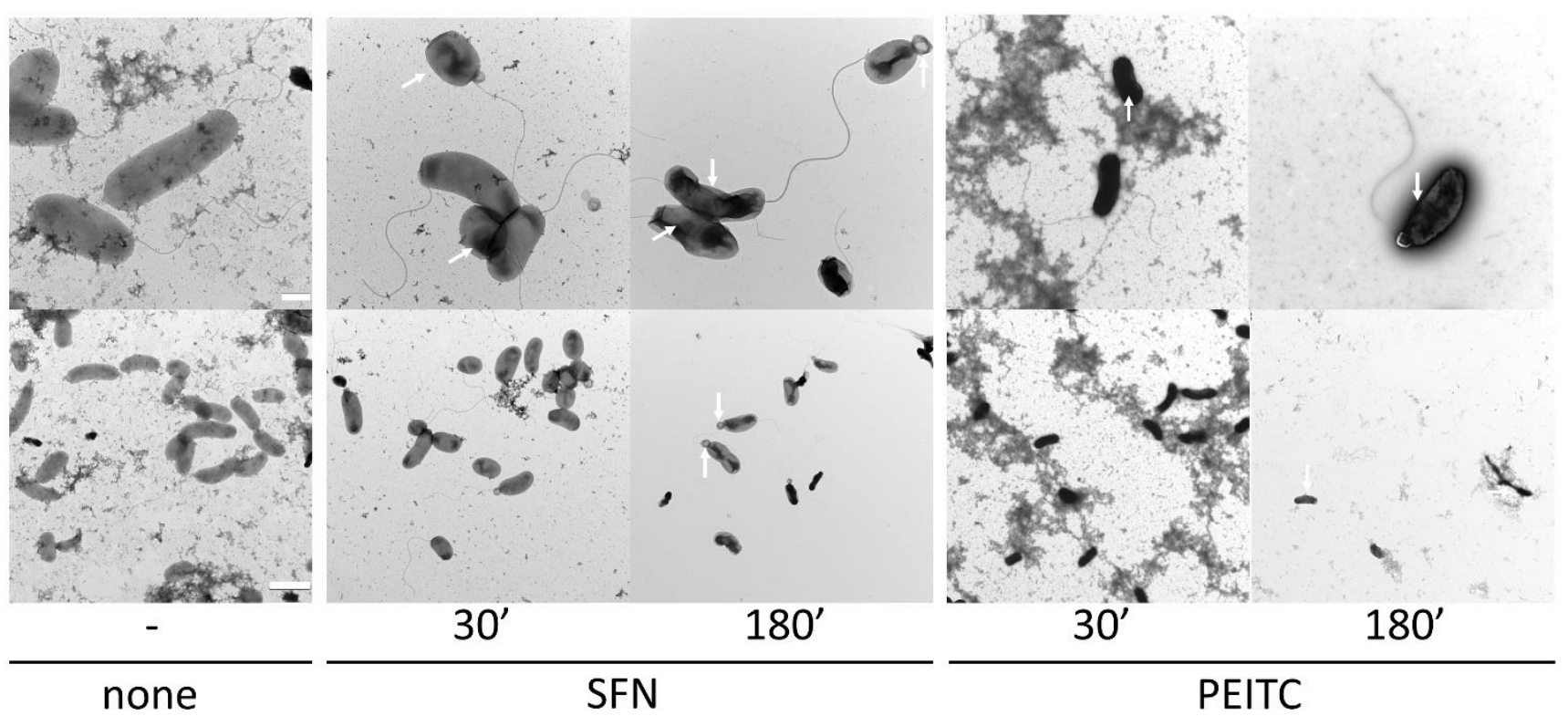

Figure 2. TEM analysis of morphological changes after ITC treatment. Cells treated with MIC of SFN or PEITC after different treatment times $(30,180 \mathrm{~min})$ at $37^{\circ} \mathrm{C}$, or none for control experiment. The white arrows indicate shape malformations and cytosol leakage. White bars indicate the scale: $0.5 \mu \mathrm{m}$ and $2 \mu \mathrm{m}$ for the upper panel and the bottom panel, respectively.

\subsection{Starvation as a Mode of ITC Action against V. cholerae}

It has been proposed that cytosol shrinkage might be one of the results of cell starvation [40]. According to Shi and colleagues, the condensation of cytoplasm is a natural feature of cells experiencing nutrient depletion. However, the prolonged metabolic stress observed in starved cells might lead to membranes dysfunction and loss of their potential [41,42]. In our previous studies, we showed that ITC treatment resulted in stringent response activation and a drastic decrease in nucleic acids synthesis as a consequence of the accumulation of starvation alarmone, (p)ppGpp [22,25]. Thus, we compared SFN and PEITC effect on RNA/DNA synthesis in $\left[{ }^{3} \mathrm{H}\right]$ radiolabeled nucleotide assay. A significant reduction of stable RNA synthesis was observed (Figure 3a,b), which indicates that general downregulation of major metabolic processes occurs rapidly after SFN or PEITC treatment as a result of the global stress response. We also observed the impaired DNA synthesis in treated cultures as assessed by $\left[{ }^{3} \mathrm{H}\right]$ thymidine incorporation (Figure $3 \mathrm{c}, \mathrm{d}$ ). To determine whether the stringent response alarmone accumulated after the ITC treatment, we measured the levels of the $\left[{ }^{32} \mathrm{P}\right]$ labeled nucleotides in the treated cells. This examination showed that under treatment with SFN or PETC, the (p)ppGpp alarmone levels increased and were comparable to those observed in $V$. cholerae cultures experiencing amino acid deprivation, which was induced by the addition of serine hydroxamate (SHX), the toxic analog of L-serine. Namely, the SFN or PEITC treatment for $15 \mathrm{~min}$ (at MIC) resulted in the accumulation of ppGpp ( $\pm 162.5 \%$ and $\pm 54.5 \%$, respectively, in relation to cells treated with SHX). What is noteworthy is that both ITCs at concentrations lower than their MICs were able to significantly elevate the alarmone synthesis. SFN at $1 / 2,1 / 4$, and $1 / 8$ of MIC elevated ppGpp level up to $168.5 \%, 116.7 \%$, and $76.3 \%$, respectively (Figure 3e). The cells treated with PEITC at the $1 / 2,1 / 4$, and $1 / 8$ of MIC showed different dynamics of alarmone accumulation, namely $72 \%, 159.7 \%$, and $117.6 \%$, respectively (Figure $3 f$ ). The amounts of the detected guanosine nucleotides correlated with the inhibition of nucleotides synthesis in PEITC treated cells. At higher doses of PEITC (1/2 or 1 MIC), the GTP/GDP spots visible on chromatograms gave apparently lower signals, which suggests that the process of their synthesis was disturbed (Figure 3f). 
a

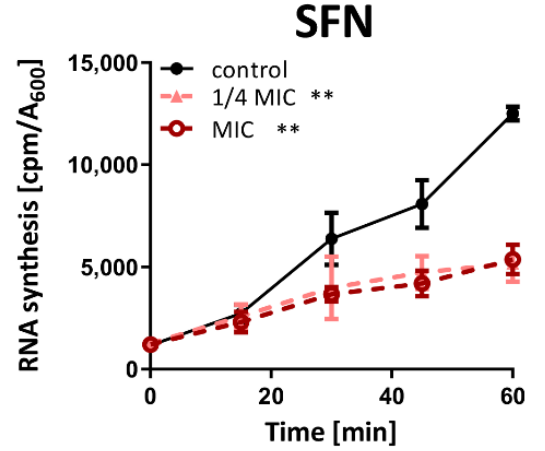

C

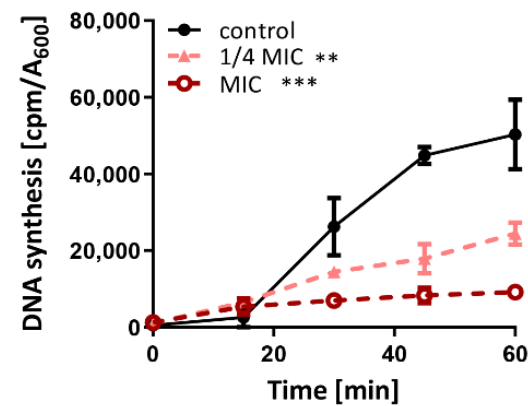

e
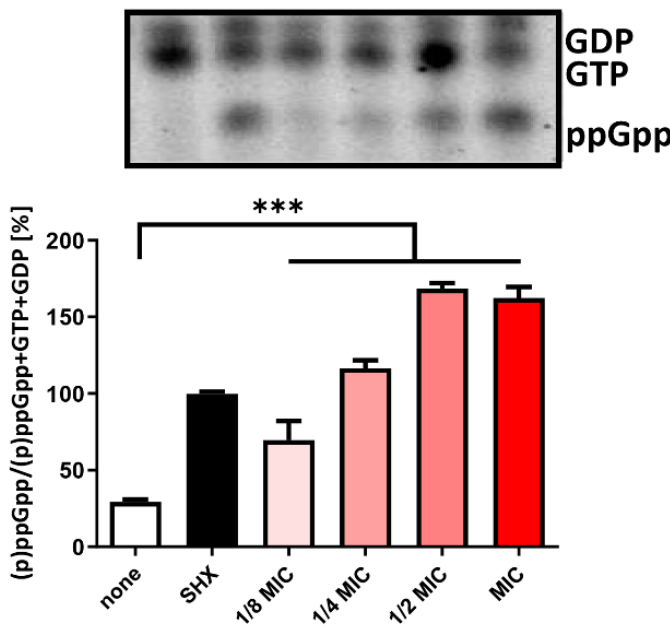

b

\section{PEITC}
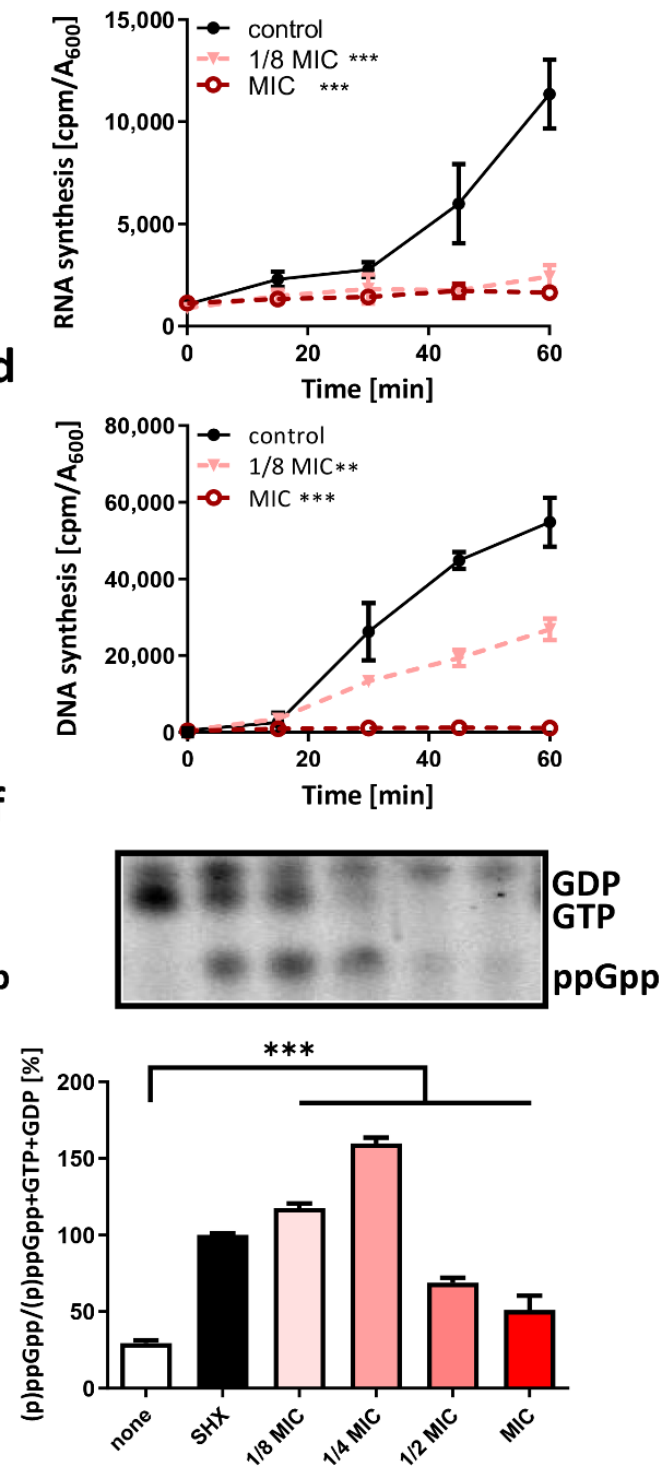

Figure 3. SFN and PEITC impair nucleic acid synthesis and activate stringent response and (p)ppGpp alarmone accumulation in $V$. cholerae. The effect of SFN (a) and PEITC (b) on RNA synthesis was assessed in $\left[{ }^{3} \mathrm{H}\right]$ uridine incorporation assay. The effect of SFN (c) and PEITC (d) on DNA synthesis assessed in $\left[{ }^{3} \mathrm{H}\right]$ thymidine incorporation assay. The (p)ppGpp alarmone level in cells treated (15 $\mathrm{min}$ ) with SFN (e) and PEITC (f). Bacteria were grown in MOPS labeling medium in the presence of $150 \mu \mathrm{Ci} / \mathrm{mL}\left[{ }^{32} \mathrm{P}\right]$ orthophosphoric acid with various concentrations of ITC or starved for amino acids by the addition of SHX. The labeled guanosine nucleotides separated on TLC are presented in the panels. The percentage of ppGpp in the total pool of guanosine nucleotides in various conditions is presented on the graphs. The results presented are mean values from 3 independent experiments. The significance of differences between the results and the control was tested using the Student's $t$-test. Statistical significance is marked with asterisks: ${ }^{* * *} p<0.001 ;{ }^{* *} p<0.01$.

The activation of the stringent response results in modulation of gene expression and dramatically changes metabolic pathways by recruitment of alternative sigma factors [43]. Therefore, the observed drop in DNA synthesis in our study might be connected to the indirect effect of the inhibition of gene expression and alarmone accumulation. (p)ppGpp generally acts as a signal of nutritional deprivation, but also physical, and other environmental changes can induce its synthesis. Its levels increase upon nutrient downshifts and are inversely correlated with growth rate $[43,44]$. In V. cholerae, (p)ppGpp is synthesized by 
two enzymes conservative for enterobacteria, RelA and SpoT, and the third one is RelV, which to date seems to be specific just for this species. In the recent studies, we showed that ITC action in E. coli relies on amino acid starvation pathway mediated by RelA [22,25], and relA deficient strain was unable to accumulate (p)ppGpp in response to ITC. It indicated that the stringent response induction by ITC is mediated by amino acid starvation. Antimicrobial activity of SFN and PEITC was also affected by the supplementation of a culture medium with several amino acids and tri-peptides [22,25,45]. Isothiocyanate group (-NCS) was proposed to be an electrophilic functional group prone to react with both amines and thiols $[46,47]$. Nonetheless, the interactions with specific cellular targets were also reported [48,49]. Luciano and colleagues showed direct enzymatic inhibition of thioredoxin reductase and acetate kinase in enterohemorrhagic E. coli O157:H7 by AITC [49]. We can assume that the observed morphological changes and metabolic downregulation of nucleic acid synthesis in $V$. cholerae as the response to tested ITC are connected with rapid elevation of (p)ppGpp levels. However, the genetic and molecular background of this phenomenon should be further investigated, especially the role of relV in the stringent response mechanism of $V$. cholerae.

\subsection{The SFN and PEITC Treatment Controls Expression of Virulence Factors of $V$. cholerae}

Rehydration and antibiotic therapy remain the first line of treatment of cholera infections. This strategy is targeted to cure the symptoms but remains blind to the serious problem, namely, the toxigenicity of bacteria due to CT production, which, in consequence, leads to severe health complications after the therapy and slows the patient convalescence. To gain insight into the potency of ITC to reduce the pathogenicity of $V$. cholera, we performed a quantitative RT-qPCR analysis of virulence genes expression (Figure 4a). The virulence of $V$. cholerae is maintained by several factors where the ToxT, ToxR, and ToxS regulatory proteins remain crucial for ctxAB genes expression called then the "ToxR regulon" after the first identified positive regulator [50].

Thus, the following genes were chosen according to their role in $V$. cholerae pathogenicity: tox $T$, to $x R$, toxS, encoding regulatory proteins; $c t x B$ the $C T$ beta subunit; $t c p H$, tcpP, and $t c p A$ as involved in toxin coregulated pilus synthesis. Moreover, because of described significant role of (p)ppGpp alarmone in effective transcription from ToxR regulon, we decided to study the genes expression pattern also in amino acid starved cells during SHX treatment. Our results indicated that a high level of (p)ppGpp, elevated due to starvation signal from RelA activity, resulted in a general decrease in the expression of tested genes in SHX-treated cells. This downregulation was observed in SFN and PEITC challenged cultures (Figure 4a). The strong and statistically significant downregulation of toxT, the main toxin synthesis regulator, was noticed in a relatively short time, 15 min after the addition of compounds, namely $-3.1,-7.6$, and -25 fold change for SFN, PEITC, and SHX, respectively. The prolonged treatment $(60 \mathrm{~min})$ resulted in a less pronounced effect, especially for PEITC and SHX. Expression of toxS and toxR was downregulated efficiently by SHX and SFN, while PEITC reduced the expression of the toxS gene only. Notably and importantly, for the prospective treatment of cholera with ITC, the toxin gene expression was reduced significantly by PEITC and SHX already 15 min after addition of compounds, while for SFN, the effective downregulation of $\operatorname{ct} x A B$ gene expression required longer (60 $\mathrm{min}$ ) exposure. The expression of genes involved in the synthesis of coregulated pilus was inhibited most effectively by SHX and SFN after longer treatment and by PEITC earlier. The Western blot analysis was used to confirm the downregulation of CT synthesis. Figure $4 \mathrm{~b}$ shows that treatment of $V$. cholerae with SFN or PEITC resulted in significant impairment of toxin synthesis after $20 \mathrm{~h}$ (80\% decrease compared to the control). Comparable results were observed for cells treated with SHX, where CT production decreased by $60 \%$. In conclusion, expression of the genes involved in $V$. cholerae virulence is downregulated by all tested compounds-ITC and amino acid starvation is induced by SHX. This is expected to reduce the pathogenicity of the bacteria. 
a
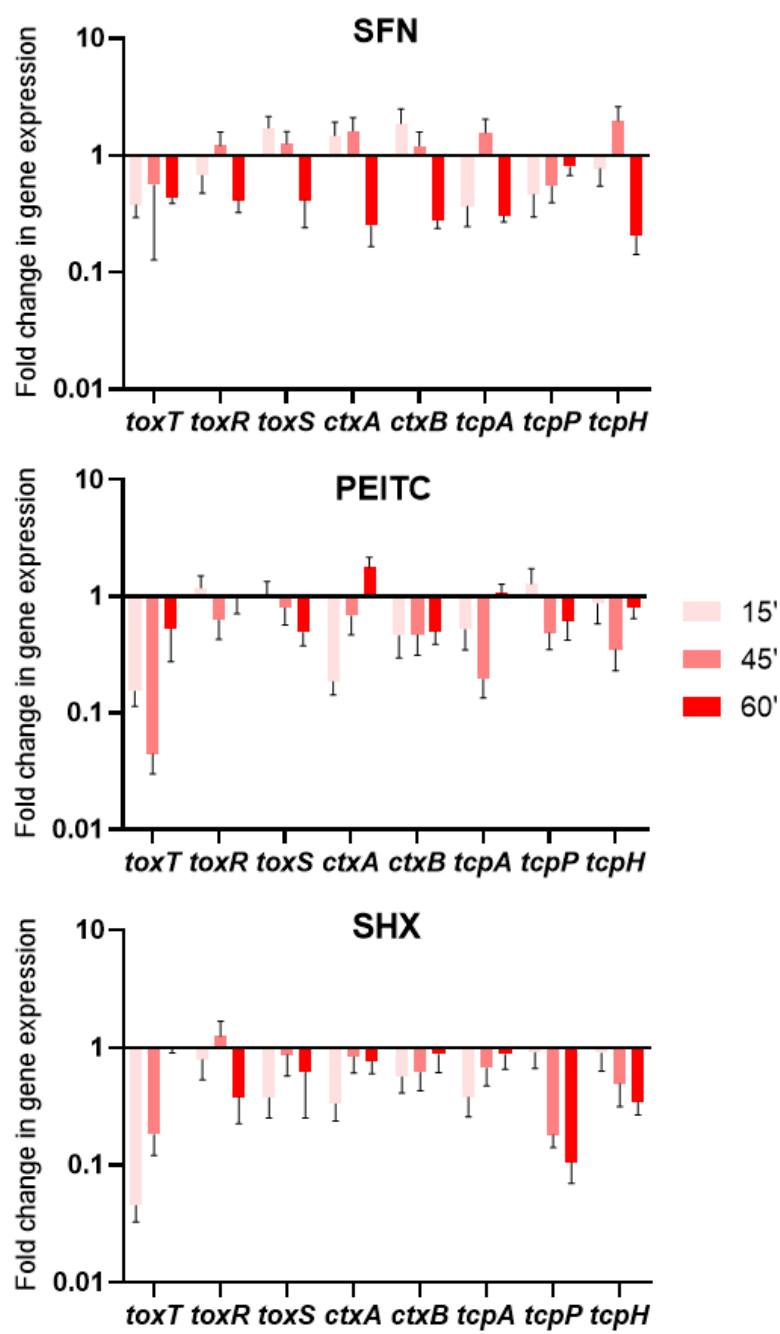

b
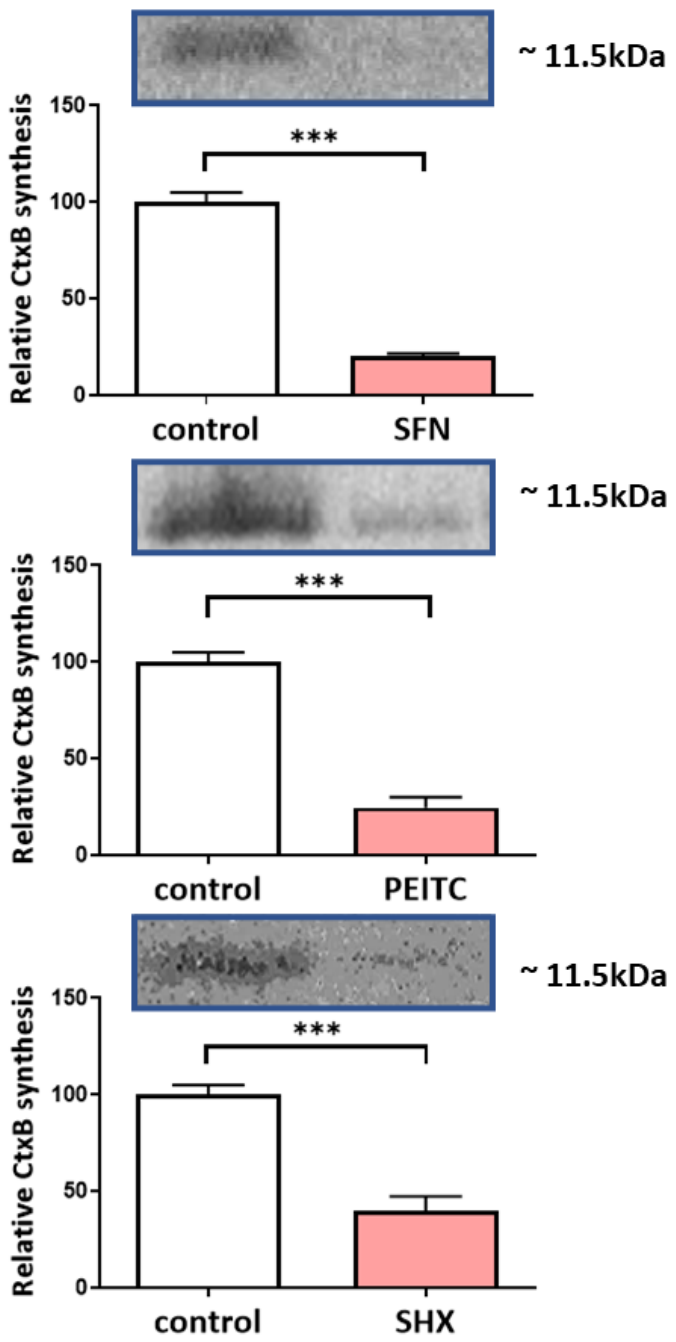

Figure 4. The expression of $V$. cholerae virulence factors is decreased by ITC treatment. (a) The genes' expression was assessed using RT-qPCR method. Transcriptional levels of various virulence-related genes were analyzed by qRT-PCR in the stringent response inducing conditions, namely treatment with SFN ( $\left.\frac{1}{4} \mathrm{MIC}\right)$, PEITC $(1 / 8 \mathrm{MIC}), \mathrm{SHX}(0.8 \mathrm{mg} / \mathrm{mL})$ for 15,45 , and $60 \mathrm{~min}$ at $37^{\circ} \mathrm{C}$. The relative transcription level of each gene was compared to the rec $A$ gene used as an internal control. $\Delta \Delta \mathrm{Ct}$ was calculated as: $\Delta \mathrm{Ct}$ (test) $-\Delta \mathrm{Ct}$ (calibrator). Ratio= efficiency ${ }^{-\Delta \Delta \mathrm{Ct}}$. (b) $\mathrm{CT}$ protein was detected by Western blot using anti-CTB rabbit monoclonal antibodies. Samples were collected after $20 \mathrm{~h}$. Toxin production was quantified densitometrically by the Quantity One (Bio-Rad). The results presented are mean values from 3 independent experiments. The Student's $t$-test statistical significance is marked with asterisks, ${ }^{* * *} p<0.001$.

It was suggested by others that a high basal level of cellular (p)ppGpp positively correlates with toxin synthesis and $V$. cholerae virulency [51]. Nevertheless, even relA deficiency was not sufficient to reduce $V$. cholerae motility, biofilm formation abilities and pathogenicity in the murine model. This apparent discrepancy can be, however, explained as Fernández-Coll and Cashel [52] described distinguished differences in the effect of alarmone accumulation on gene expression when it happens as a natural process responding to environmental nutrient availability and growth rate, and in "sudden burst" scenario in response to harsh stress conditions. Thus, we could conclude that ITC treatment leads not only to growth inhibition but also affects the virulence genes expression through the rapid elevation of cellular (p)ppGpp level. 


\subsection{ITC Reduces the Toxicity of V. cholera In Vitro and In Vivo}

Cholera infection symptoms strictly correspond to effective CT production in the host organism. Thus, downregulation of toxin synthesis together with growth inhibition by antibiotic compounds could provide higher efficiency than the traditional treatment. To evaluate the ITC effectiveness as anti-cholera agents, we checked their activity in human and simian cell lines, HeLa and Vero. These cell lines are suitable to test $V$. cholerae pathogenicity because of their sensitivity to $\mathrm{CT}$, and they are also routinely used to test the cytotoxicity of different compounds [53,54]. We showed a significant reduction of the toxic effect of bacterial lysates treated prior with any of the compounds, SFN and PEITC (Figure 5). Observed results were similar in both cell lines. The slight differences in the activity of SFN and PEITC between cell lines could be related to the variation of the glycolipid receptor (GM1) expression on the cell surface, which may impact their sensitivity to CT $[55,56]$. These findings are in line with results showing toxin expression impairment presented above. Moreover, we show that ITC is not toxic by itself for eukaryotic cell lines in doses employed in this study.

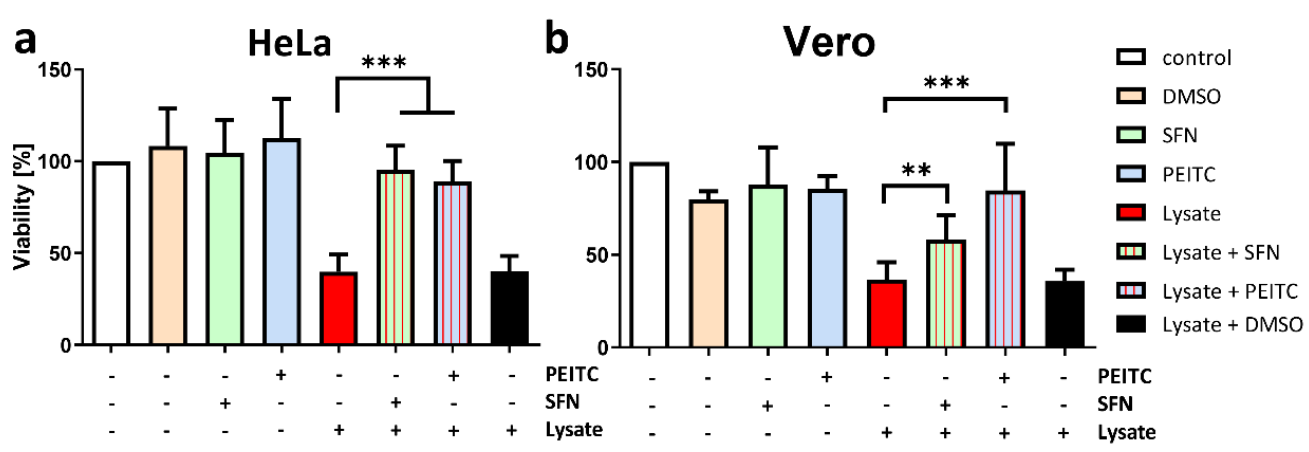

Figure 5. SFN and PEITC reduce the toxicity of $V$. cholerae against HeLa and Vero cell cultures. Bacterial lysates were obtained after centrifugation of $10^{11}$ cells from culture supplemented with ITC and culture without treatment (negative control). HeLa and Vero cells $\left(2 \times 10^{3}\right)$ were grown in DMEM medium. The viability of HeLa (a) and Vero (b) cells after treatment with ITC and bacterial lysate was measured using the MTT assay. Cytotoxicity control of the vehicle (DMSO), SFN, and PEITC were assessed as indicated on the graphs. The results presented are mean values from 3 independent experiments. The significance of differences between the results and the positive control (bacterial lysate with CT) was tested using the Student's $t$-test. Statistical significance is marked with asterisks: $* * *<<0.001 ; * * p<0.01$.

Further, in order to determine if the inhibition of virulence assessed in vitro could also affect in vivo infection, we tested the ability of SFN to inhibit virulence of $V$. cholerae in a surrogate host of Galleria mellonella larvae. This model organism was described as a suitable alternative for vertebrates in selecting new antimicrobials as well as for $V$. cholerae infections approaches $[57,58]$. We first established the bacterial load appropriate for survival experiments (Figure S2). The $5 \times 10^{2}$ bacteria per larvae were chosen for further analyzes as they resulted in a $50 \%$ death rate at $24 \mathrm{~h}$ after infection. SFN safety (at the 25,10 , and $5 \mathrm{mg} / \mathrm{kg}$ doses) was assessed, and the tested concentrations were found to be non-toxic, and no symptoms of melanization-associated with the worsening of the insect condition were observed after the treatment (data not shown). This dose corresponds with results obtained in the rodent model, assessed by others [59,60]. We demonstrate that the pretreatment of larvae with $25 \mathrm{mg} / \mathrm{kg} \mathrm{SFN}$ administrated $3 \mathrm{~h}$ before infection improved the survival of G. mellonella larvae by $60 \%$ after $48 \mathrm{~h}$ and by $30 \%$ after $72 \mathrm{~h}$ post infection (Figure 6 ). Additionally, we analyzed the potency of SFN to enhance azithromycin $(20 \mathrm{mg} / \mathrm{kg})$ activity against $V$. cholerae. Azithromycin is considered an antibiotic of choice for diarrheal treatment in children [61] and is now under clinical trial investigation. The observed larvae survival rate after a single dose of azithromycin treatment was surprisingly similar to the level observed in the objects which received SFN alone. Interestingly, administration of two 
compounds together decreased mortality in $V$. cholerae challenged larvae to $20 \%$ after $96 \mathrm{~h}$ as compared with infected control.

a

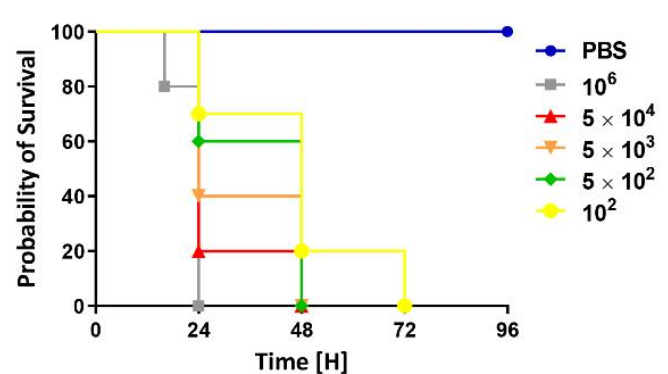

b

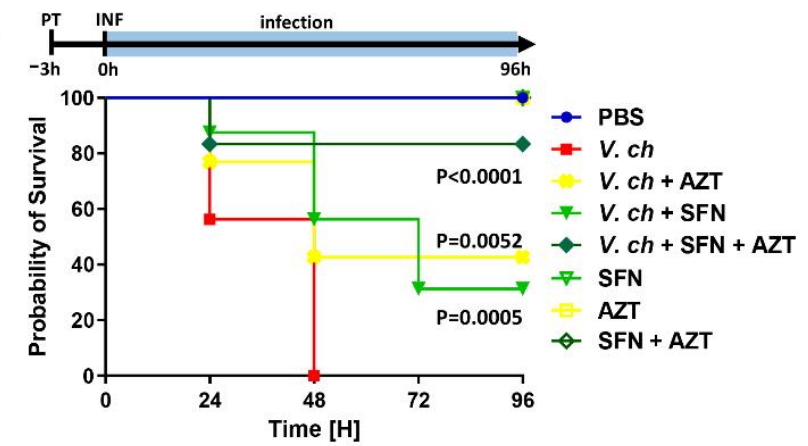

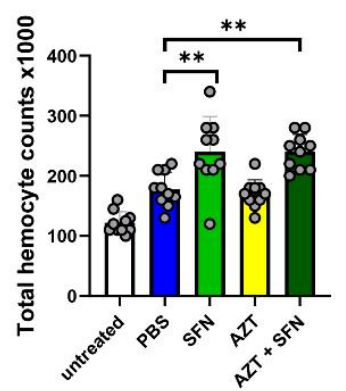

d

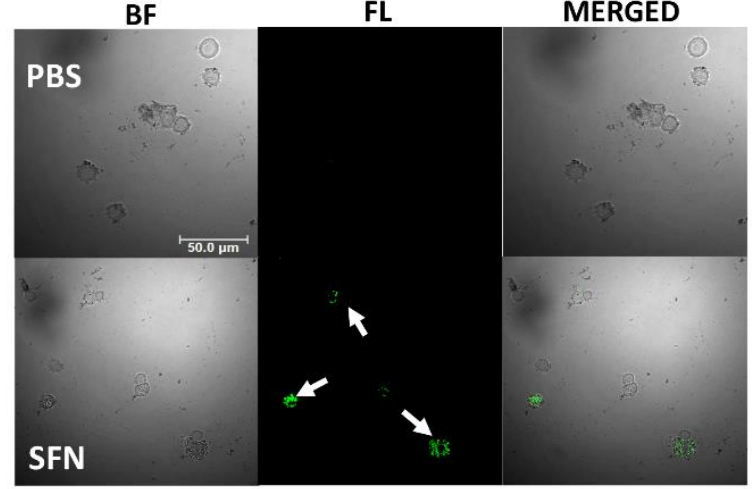

e

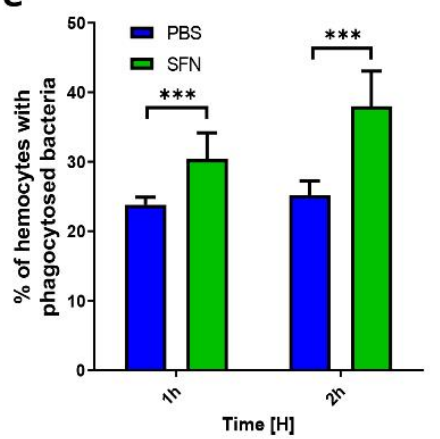

Figure 6. G. mellonella larvae pretreatment with SFN improve their survival rate after V. cholerae infection. (a) Kaplan-Meier survival analysis of Galleria mellonella larvae infected with Vibrio cholerae O395. Larvae $(\mathrm{n}=15)$ were injected with $(10 \mu \mathrm{L})$ PBS (blue circle) or $V$. cholerae suspension in PBS at range of c.f.u/per dose: $10^{2}$ (yellow circle) or $5 \times 10^{2}$ (green deltoid) or $5 \times 10^{3}$ (orange triangle) or $5 \times 10^{4}$ (red triangle) or $10^{6}$ c.f.u (gray squares). (b) Treatment efficacy assessed by survival analysis. Larvae $(\mathrm{n}=15)$ were pre-treated ( $3 \mathrm{~h}$ before infection) with SFN (light green triangle) or AZT (yellow cross) or SFN + AZT (dark green deltoid). Infection groups (filled symbols) were then injected $\left(\mathrm{t}=0\right.$ h) with $5 \times 10^{2}$ c.f.u of bacterial suspension $(V . c h)$, not treated control is represented by red squares. Not infected control groups are marked as empty symbols. Double injection with PBS was performed in the uninfected control group (blue circle). Larvae were injected and monitored as indicated on the timeline above graph. PT- pretreatment INF- infection. (c) Total hemocyte infiltration to hemolymph $(3 \mathrm{~h}$ ) in larvae injected with PBS (blue), SFN (light green), AZT (yellow), SFN + AZT (dark green) or not treated (white), individual. (d) Representative images of infected hemocytes are shown. The fluorescent signal of FITC-labeled bacteria is indicated by arrows. Scale bar upper left panel denotes $50 \mu \mathrm{m}$ and applies to the rest of the micrographs. BF-bright light; FL-fluorescence (e) Quantification of the phagocytosis percentage. The significance of differences between the results and the control was tested using the Student's $t$-test. Statistical significance is marked with asterisks: ${ }^{* * *} p<0.001 ;{ }^{* *} p<0.01$.

The SFN is known for its anti-inflammatory and antioxidant properties but is also described as an immune response stimulator [62]. Ali et al. [63] showed improved clearance of E. coli and S. aureus, where SFN treatment significantly reduced intracellular bacteria survival of THP-1 and PBMC-derived macrophages. Our results show significantly enhanced hemocytes infiltration to hemolymph $3 \mathrm{~h}$ after SFN treatment (Figure 6c) compared to PBS treated control larvae. We also observed the $27.7 \%$ enhancement of phagocytosis rate (Figure $6 \mathrm{~d}, \mathrm{e}$ ) by hemocytes obtained from $\mathrm{G}$. mellonella injected with SFN. These results were assessed by fluorescence microscopy analysis of heat-killed FITC-labeled $V$. cholerae bacteria. But yet, the detailed mechanism of this observation should be elucidated to define SFN-triggered cellular factors. Deramaudt et al. [64] proposed a combinatory mechanism where reduction of the inflammatory response through modulation of p38 and JNK signaling pathways accompanied antibacterial action of SFN in mice macrophages infected with S. aureus. A similar mode of action may operate in G. mellonella, especially as 
this organism possesses counterpart MAP kinases, and they are activated in response to infection with the entomopathogenic bacterium Bacillus thuringiensis $[65,66]$ Finally, the dosages chosen for in vivo virulence assay were comparable to those used and reported as safe to treat human diseases. Therefore, based on its effects, as well as a low toxicity, SFN could be considered as a support to current therapies for the management of cholera as monotherapy and for the combination with other antibiotics. However, further studies are needed to elucidate the molecular mechanisms underlying the activity of ITCs and also to identify their new molecular targets.

\section{Materials and Methods}

\subsection{Bacterial Isolates and Growth Conditions}

$V$. cholerae O395 (WT) [67] and toxT::lacZ [68] mutant were grown in LB medium (Sigma Aldrich, USA) at $37^{\circ} \mathrm{C}$ or $30^{\circ} \mathrm{C}$ (as indicated below) with aeration and shaking or plated on LB agar (supplemented with $1.0 \%$ bacteriological agar) and incubated overnight at $37^{\circ} \mathrm{C}$ or $30^{\circ} \mathrm{C}$. For assessing the (p)ppGpp accumulation MOPS a medium with $0.2 \%$ casamino acids was used. For determination of susceptibility tests Mueller-Hinton (Sigma Aldrich, Burlington, MA, USA) medium was used.

\subsection{Determination of Bacterial Growth Inhibition}

The mechanism of ITC antimicrobial activities was tested according to CLSI standard methodology M07-A10. The MIC (minimal inhibitory concentration) was assessed by the twofold broth microdilution methods as described previously [69]. Mueller medium was used to prepare bacterial inoculums and to dilute the PEITC and SFN stock solution. Briefly, fresh $V$. cholerae culture containing 0.5 McFarland of bacteria was diluted 200 times, the Mueller-Hinton medium was added in equal volume to prepared twofold dilution of SFN and PEITC. Initial culture started from $5 \times 10^{5}$ cells per well on 96-well plates. For inoculum control, $10 \mu \mathrm{L}$ of untreated culture was resuspended in a $10 \mathrm{~mL}$ culture medium and spread $(100 \mu \mathrm{L})$ on agar plates to enumerate c.f.u. after overnight incubation in $37^{\circ} \mathrm{C}$. The MIC of ITCs was defined at the lowest concentration inhibiting visible growth of bacteria after overnight incubation $(20 \mathrm{~h})$ at $37^{\circ} \mathrm{C}$ and determined spectrophotometrically using EnSpire microplate reader (Perkin Elmer Singapore Pte. Ltd., Singapore). The MBC was measured by subculturing the cultures used for MIC determination onto fresh agar plates. MBC was the lowest concentration of a drug that results in killing $99.9 \%$ of the bacteria being tested.

\subsection{Time-Kill Assay}

The time-kill test was performed according to the CLSI guidelines and Zhou et al. [70]. $V$. cholerae O395N1 toxT::lacZ strain was grown in Mueller-Hinton medium on 96- well plates. After ITC $(10 \times \mathrm{MIC}, 5 \times \mathrm{MIC}, 2 \times \mathrm{MIC}, \mathrm{MIC})$ addition, samples were collected at 0,2 , $4,6,8,10,12$, and $24 \mathrm{~h}$ of growth, and the colony-forming units were numbered by plating serial dilutions onto $\mathrm{MH}$ agar plated after incubation for $24 \mathrm{~h}$ at $37^{\circ} \mathrm{C}$ in microaerobic conditions. The experiment was performed in triplicate.

\subsection{Biofilm Eradication}

Biofilm formation of $V$. cholerae O395N1 toxT::lacZ was assessed in sterile 96-well polystyrene microtiter plates. Overnight cultures were added to microtiter plates to form biofilms for $24 \mathrm{~h}$. The plates were incubated for $24 \mathrm{~h}$ at $30^{\circ} \mathrm{C}$. Afterwards, the medium was removed, and the biofilms were exposed to SFN or PEITC (at MIC and $5 \times$ MIC) for $1 \mathrm{~h}$. Sterile Mueller-Hinton medium was used as a control. Then, the biofilm mass and viability were determined in crystal violet ( $1 \%)$ and MTT $(0.5 \%)$ assays, respectively, according to the manufacturer's protocols. 


\subsection{Measurement of DNA and RNA Synthesis}

The estimation of nucleic acid synthesis was performed by measurement of incorporation of radioactive precursors, $\left[{ }^{3} \mathrm{H}\right]$ thymidine for DNA, and $\left[{ }^{3} \mathrm{H}\right]$ uridine for RNA, according to the procedure described in [22]. Briefly, overnight bacterial cultures were diluted in fresh LB medium 1:100 and grown to $\mathrm{A}_{600}$ of 0.1 . Isotope was added at $150 \mu \mathrm{CI}$. At the time points, $50 \mu \mathrm{L}$ of samples were withdrawn and placed onto Whatman filter paper and then transferred immediately to ice-cold 10\% trichloroacetic acid (TCA), next Whatman filter paper was washed in 5\% TCA and twice in 96\% ethanol. The filters were dried, and radioactivity was measured in a scintillation counter MicroBeta2 (PerkinElmer, Downers Grove, IL, USA). Results from three independent experiments were normalized to bacterial culture density.

\subsection{RNA Extraction, Reverse Transcription, Primers, and qPCR Analysis}

The RT-qPCR analyzes of gene expression were performed as described elsewhere [71]. Briefly, V. cholerae (wild type) was cultivated aerobically at $37^{\circ} \mathrm{C}$ overnight, then moved to a fresh medium (1:100). The culture was grown to $\mathrm{OD}_{600}=0.1$. and compounds were added as indicated. Samples were taken at time zero, 15, 45, and $60 \mathrm{~min}$. Total RNA was extracted using RNeasy Mini Kit (Qiagen GmbH, Hilden, Germany) according to the manufacturer's protocol. The total RNA concentration and purity of samples were assessed using Agilent RNA Kits (2100 Bioanalyzer System, Agilent Technologies, Santa Clara, CA, USA). Next, reverse transcription was performed using EvoScript Universal cDNA Master (Roche, Basel, Switzerland). Subsequently, quantification of transcripts in samples was performed by real-time qPCR analysis using SYBR Green-based method. The experiment was carried out in LightCycler ${ }^{\circledR} 480$ instrument (Roche Diagnostics AG, Rotkreuz, Switzerland). Briefly, the qPCR reaction $(10 \mu \mathrm{L})$ contained: $1 \times$ SYBR Green I Master Mix, oligonucleotides (primer list, Table S1), and $1 \mu \mathrm{L}$ of cDNA template $(20 \mathrm{ng} / \mu \mathrm{L})$ obtained in a previous step. The qPCR assay was performed with the following amplification program: activation of the enzyme at $95^{\circ} \mathrm{C}$ for $10 \mathrm{~min}$., followed by 45 cycles of $95^{\circ} \mathrm{C}$ for $10 \mathrm{~s}, 60^{\circ} \mathrm{C}$ for $10 \mathrm{~s}$, and $72{ }^{\circ} \mathrm{C}$ for $10 \mathrm{~s}$. Melting curve analysis of the PCR products was performed to ensure the specificity of the products. Normalization was done by the amount of the total RNA in each RT reaction and by the level of expression of a reference gene recA.

\subsection{In Vitro Cultures Toxicity Assay}

The Hela and Vero cells were cultivated in DMEM (Gibco, Waltham, MA, USA) supplemented with $10 \%$ horse serum (Gibco, Waltham, MA, USA) along with penicillin G and streptomycin and maintained at $37^{\circ} \mathrm{C}$ in an atmosphere of humidified $5 \% \mathrm{CO}_{2-} 95 \%$ air in a $\mathrm{CO}_{2}$ incubator. In order to evaluate the activity of CT in HeLa or Vero cells, bacterial lysates were prepared using WT strain as we reported previously [25] with minor changes. Briefly, overnight cultures were grown in LB medium $\left(30^{\circ} \mathrm{C}, 165 \mathrm{rpm}\right)$. After 100 -fold dilution in fresh LB medium, the cultivation was continued until the $\mathrm{OD}_{600}=0.1$ was reached. Then, SFN $\left(\frac{1}{2}\right.$ MIC) and PEITC $\left(\frac{1}{4}\right.$ MIC) were added to the culture and incubated with shaking for $360 \mathrm{~min}$. Next, lysates were withdrawn, samples normalized to $10^{11}$ cells per group and centrifuged ( $4200 \mathrm{rpm}, 20 \mathrm{~min}, 4^{\circ} \mathrm{C}$ ), the pellet was suspended in $1 \mathrm{x}$ PBS and subjected to a 3-fold freezing and thawing cycle in liquid nitrogen, the lysate was filtered using syringe filters (PVDF, $0.22 \mu \mathrm{m}$, Roth, Karlsruhe, Germany).

Cell viability was determined by the MTT method as previously described [25]. Cells were plated in four repetitions $\left(2 \times 10^{3}\right.$ cells/well) of 96-well flat-bottomed plates and incubated overnight prior to ITCs and cholera toxin exposure. Then the medium was changed to a fresh one supplemented with test compounds. $5 \mu \mathrm{L}$ of diluted bacterial lysates ( $1 \mathrm{~mL}$ medium $+40 \mu \mathrm{L}$ bacterial lysates) were added to $95 \mu \mathrm{L}$ DMEM. The control experiments with appropriate concentrations of compounds were performed. After $48 \mathrm{~h}$ medium was changed to MTT solution $(5 \mathrm{mg} / \mathrm{mL}$ in $1 \times \mathrm{PBS})$, cells were incubated with MTT solutions for $2 \mathrm{~h}$. Then the violet formazan product was dissolved in $100 \mu \mathrm{L}$ DMSO 
and measured at $570 \mathrm{~nm}$ and $660 \mathrm{~nm}$ using Victor3 plate reader (Wallac Oy, Perkin Elmer, Turku, Finland).

\subsection{Assessment of ( $p) p p G p p$ Accumulation Levels in Cells after ITC's Treatment}

The measurement of cellular guanosine tetra-phosphate (ppGpp) level was based on the $\left[{ }^{32} \mathrm{P}\right]$-labeling of nucleotides method developed by thin-layer chromatography on PEI-cellulose plates [72]. Fresh $V$. cholerae culture was suspended in PBS to obtain $\mathrm{OD}_{600}=1.0$ on the McFarland scale as measured by a Densila-Meter II (ErbaLachema, Brno, Czech Republic). The suspension was diluted at a 1:10 ratio in a minimal MOPS medium containing $0.4 \mathrm{mM} \mathrm{KH}_{2} \mathrm{PO}_{4}\left(0.2 \%\right.$ casamino acids). Then, the $\left[{ }^{32} \mathrm{P}\right]$-orthophosphoric acid was added to the cultures to a final concentration of $150 \mu \mathrm{Ci} / \mathrm{mL}$, and bacteria were grown at $37{ }^{\circ} \mathrm{C}$ for $1 \mathrm{~h}$ with shaking $165 \mathrm{rpm} / \mathrm{min}$. After this time, the bacterial cultures $(150 \mu \mathrm{L})$ were transferred to wells in a 96-well plate. SFN, PEITC in a range of concentrations were added. The amino acid starvation was induced by adding an L-serine amino acidserine hydroxamate ( $\mathrm{SHX}$ ) analogue to a final concentration of $0.8 \mathrm{mg} / \mathrm{mL}$ to the bacterial cultures. Samples were collected at the indicated time, then extracted with formic acid $(13 \mathrm{M})$ in two cycles of freezing and thawing in liquid nitrogen. Samples were centrifuged $(5000 \times g, 5 \mathrm{~min})$, and the nucleotides present in the supernatant were separated by thin layer chromatography on a polyethyleneimine (PEI) TLC plate with cellulose in $1.5 \mathrm{M}$ potassium phosphate buffer and analyzed with Typhoon 9200 (GE Healthcare, Sweden).

\subsection{Galleria Mellonella Model of Infection Procedures}

G. mellonella larvae TruLarve were used to perform analysis (BioSystems Technology, Credition, UK). The survival and cytotoxicity experiments were performed according to the manufacturer's protocols. Larvae were injected with $10 \mu \mathrm{L}$ of solution (bacterial suspension, antibiotic or PBS) into the last proleg using a blunt tip $50 \mu \mathrm{L}$ syringe (Hamilton). Surface sterilization of insects with EtOH was performed prior to each loading. The larvae were then incubated at $37^{\circ} \mathrm{C}$, and survival and melanization were recorded in the next $96 \mathrm{~h}$. Larvae were scored as dead when they ceased moving, changed from their normal pale cream coloration to brown, and failed to respond when gently manipulated with a pipette tip. PBS-injection controls were used. Survival $96 \mathrm{~h}$ post-infection was recorded.

\subsubsection{Virulence and Treatment of $V$. cholerae Infection in G. mellonella}

The wax moths, whose weights were $250 \pm 25 \mathrm{mg}$, with no symptoms of melanization were divided into different groups. Fist, the virulence of $V$. cholerae O395 was assessed by challenging larvae with range of c.f.u/mL $\left(10^{6}, 5 \times 10^{5}, 5 \times 10^{4}, 5 \times 10^{3}, 5 \times 10^{2}\right)$ of bacteria washed and suspended in PBS. The safety of SFN and AZT administration was tested at doses $25,10,5 \mathrm{mg} / \mathrm{kg}$, and $20 \mathrm{mg} / \mathrm{kg}$, respectively. Next, the effectiveness of drugs was assessed by pretreatment of larvae by injection $(10 \mu \mathrm{L})$ of SFN $(25 \mathrm{mg} / \mathrm{kg})$, AZT $(20 \mathrm{mg} / \mathrm{kg})$, or both agents in mixture into the last left proleg at $3 \mathrm{~h}$ before inoculum $\left(5 \times 10^{2}\right.$ c.f.u) administration $(10 \mu \mathrm{L})$ into the right proleg. The survival rate was then monitored at $24 \mathrm{~h}$ intervals. Fifteen larvae per group were used and each experiment was assessed in triplicate.

\subsubsection{FITC Labeling of Bacteria}

FITC labeling of bacteria was performed as described elsewhere [73]. Briefly, bacteria were harvested from exponential phase cultures and heat-killed $\left(1 \mathrm{~h}\right.$ at $\left.70{ }^{\circ} \mathrm{C}, 10^{9} / \mathrm{mL}\right)$. Then, cells were incubated in $0.5 \%$ carbonate buffer $(\mathrm{pH} 9.5)$ containing FITC $(0.1 \mathrm{mg} / \mathrm{mL})$ for $30 \mathrm{~min}$ at $37^{\circ} \mathrm{C}$. The FITC-conjugated bacteria were then washed three times in PBS and kept at $-20^{\circ} \mathrm{C}$ until use.

\subsubsection{In Vivo Phagocytosis Assay}

For in vivo assays, $10 \mu \mathrm{L}$ of PBS solution containing approximately $5 \times 10^{7}$ cells of FITC-labeled $V$. cholerae were injected into $G$. mellonella via the last left proleg using a 
$50 \mu \mathrm{L}$ Hamilton syringe. After 1 and $2 \mathrm{~h}$ at $28^{\circ} \mathrm{C}$, the insects were surface sterilized and bled directly onto a glass coverslip in a drop of PBS. After $10 \mathrm{~min}$ of incubation at room temperature, a fluorescence-quenching assay was achieved by adding $0.5 \mathrm{~mL}$ of trypan blue dye $(0.5 \%$ in PBS) and incubated for $15 \mathrm{~min}$. Cells were then washed in $\mathrm{NaCl}$ solution $(8 \mathrm{~g} / \mathrm{L})$ and fixed in $3.7 \%$ paraformaldehyde in PBS for $10 \mathrm{~min}$. Phagocytosis was assessed by fluorescence microscopy using Leica DMI4000B microscope fitted with a DFC365FX camera (Leica Microsystems, Germany). To quantify the rate of phagocytosis and the phagocytic index for each coverslip, five fields that contained at least 100 hemocytes were examined. The rate of phagocytosis was calculated according to the following formula: Phagocytic rate $=(($ phagocytic hemocyte $) /($ total hemocyte $)) \times 100 \%$.

\subsection{Transmission Electron Microscopy (TEM)}

The MIC of SFN and PEITC were added to bacterial cultures $\left(\mathrm{OD}_{600}=0.4\right)$ and incubated in $37 \circ \mathrm{C}$. Nontreated cultures were used as control. Next, at the time indicated, bacteria were pelleted by centrifugation $(4000 \times g, 10 \mathrm{~min})$ and resuspended in a fresh medium. $5 \mu \mathrm{L}$ of the diluted (100 times) bacteria culture (before or after laser treatment) was dropped and dried on a copper grid for TEM observation. Electron microscopic analyses were performed using the Tecnai Spirit BioTWIN microscope (FEI Company, Eindhoven, Netherlands) at $120 \mathrm{kV}$.

\subsection{Statistical Analysis}

The data are expressed as the means $\pm \mathrm{SD}$. Two-tailed unpaired Student's $t$-tests were used to analyze the differences between experimental groups with the exception of KaplanMeier survival assays of G. mellonella, where Chi-square analyzes were performed. All experiments were repeated at least three times independently for reproducibility. Technical repeats were performed where indicated. $p$ values $<0.05$ were considered statistically significant. GraphPad Prism 8 software (GraphPad Software, San Diego, CA, USA) was used for statistical analysis.

\section{Conclusions}

Our results indicate a two-way mechanism of action of ITC against $V$. cholerae: inhibition of bacterial growth (both in plankton and biofilm) and suppression of toxin production. They efficiently protect mammalian cells and G. mellonella larvae against $V$. cholera toxicity at concentrations safe for the host cells. Therefore, they constitute promising candidates for the treatment of $V$. cholera infections, either as monotherapy or as a combination with antibiotics. Stringent response activation by ITC is considered the most likely mechanism underlying metabolic disturbances in treated bacteria. However, further studies are needed to elucidate this phenomenon and its implication for future utility in the control of $V$. cholerae infections.

Supplementary Materials: The following are available online at https:/ /www.mdpi.com/article/10 $.3390 /$ ijms221910187/s1.

Author Contributions: Conceptualization, D.N., A.H.-A. and A.S.-P.; methodology, K.K. and D.N.; formal analysis, K.K. and D.N.; investigation, K.K., A.P.-F., M.N., M.K. and D.N.; writing-original draft preparation, D.N.; writing — review and editing, D.N., A.S.-P. and A.H.-A.; visualization, D.N and K.K.; supervision, D.N. and A.S.-P.; funding acquisition, A.S.-P. and D.N. All authors have read and agreed to the published version of the manuscript.

Funding: This research was funded by the National Science Center, Poland (grant number 2013/11/ B/NZ2/02582 and 2016/21/B/NZ7/02077) to A.S.-P., the Foundation for Polish Science, Poland (START $059.2017 * 7 \mathrm{E} 9$ ) to D.N., and the APC was funded by University of Gdansk.

Institutional Review Board Statement: Not applicable.

Informed Consent Statement: Not applicable. 
Acknowledgments: We kindly thank Mekalanos for bacterial strains. We are grateful to Katarzyna Potrykus, Monika Maciag-Dorszyńska, Grzegorz Cech and Krystyna Bogucka for discussion and support.

Conflicts of Interest: Authors declare no conflict of interest.

\section{References}

1. Kaper, J.B.; Morris, J.G.; Levine, M.M. Cholera. Clin. Microbiol. Rev. 1995, 8, 48-86. [CrossRef]

2. Sack, D.A.; Sack, R.B.; Nair, G.B.; Siddique, A. Cholera. Lancet 2004, 363, 223-233. [CrossRef]

3. Deen, J.; Mengel, M.A.; Clemens, J.D. Epidemiology of cholera. Vaccine 2020, 38, A31-A40. [CrossRef] [PubMed]

4. Clemens, J.D.; Nair, G.B.; Ahmed, T.; Qadri, F.; Holmgren, J. Cholera. Lancet 2017, 390, 1539-1549. [CrossRef]

5. Chatterjee, S.; Asakura, M.; Chowdhury, N.; Neogi, S.B.; Sugimoto, N.; Haldar, S.; Awasthi, S.P.; Hinenoya, A.; Aoki, S.; Yamasaki, S. Capsaicin, a potential inhibitor of cholera toxin production in Vibrio cholerae. FEMS Microbiol. Lett. 2010, 306, 54-60. [CrossRef] [PubMed]

6. Verma, J.; Bag, S.; Saha, B.; Kumar, P.; Ghosh, S.; Dayal, M.; Senapati, T.; Mehra, S.; Dey, P.; Desigamani, A.; et al. Genomic plasticity associated with antimicrobial resistance in Vibrio cholerae. Proc. Natl. Acad. Sci. USA 2019, 116, 6226-6231. [CrossRef] [PubMed]

7. Dutta, D.; Kaushik, A.; Kumar, D.; Bag, S. Foodborne Pathogenic Vibrios: Antimicrobial Resistance. Front. Microbiol. 2021, 12, 638331. [CrossRef]

8. Kaunitz, J.D. Oral Defense: How Oral Rehydration Solutions Revolutionized the Treatment of Toxigenic Diarrhea. Dig. Dis. Sci. 2020, 65, 345-348. [CrossRef]

9. Zahid, M.S.H.; Awasthi, S.P.; Asakura, M.; Chatterjee, S.; Hinenoya, A.; Faruque, S.M.; Yamasaki, S. Suppression of virulence of toxigenic vibrio cholerae by anethole through the cyclic AMP (cAMP)-cAMP receptor protein signaling system. PLoS ONE 2015, 10, e0137529. [CrossRef]

10. Silva, A.J.; Benitez, J.A. Vibrio cholerae Biofilms and Cholera Pathogenesis. PLoS Negl. Trop. Dis. 2016, 10, 1-25. [CrossRef]

11. Moorthy, S.; Watnick, P.I. Identification of novel stage-specific genetic requirements through whole genome transcription profiling of Vibrio cholerae biofilm development. Mol. Microbiol. 2005, 57, 1623-1635. [CrossRef]

12. Gallego-Hernandez, A.L.; Depas, W.H.; Park, J.H.; Teschler, J.K.; Hartmann, R.; Jeckel, H.; Drescher, K.; Beyhan, S.; Newman, D.K.; Yildiz, F.H.; et al. Upregulation of virulence genes promotes Vibrio cholerae biofilm hyperinfectivity. Proc. Natl. Acad. Sci. USA 2020, 117, 11010-11017. [CrossRef] [PubMed]

13. Faruque, S.M.; Biswas, K.; Nashir Udden, S.M.; Ahmad, Q.S.; Sack, D.A.; Balakrish Nair, G. Transmissibility of cholera: In vivoformed biofilms and their relationship to infectivity and persistence in the environment. Proc. Natl. Acad. Sci. USA 2006, 103, 6350-6355. [CrossRef] [PubMed]

14. Teschler, J.K.; Zamorano-Sánchez, D.; Utada, A.S.; Warner, C.J.A.; Wong, G.C.L.; Linington, R.G.; Yildiz, F.H. Living in the matrix: Assembly and control of Vibrio cholerae biofilms. Nat. Rev. Microbiol. 2015, 13, 255-268. [CrossRef]

15. Papenfort, K.; Silpe, J.E.; Schramma, K.R.; Cong, J.P.; Seyedsayamdost, M.R.; Bassler, B.L. A Vibrio cholerae autoinducer-receptor pair that controls biofilm formation. Nat. Chem. Biol. 2017, 13, 551-557. [CrossRef] [PubMed]

16. Aires, A.; Mota, V.R.; Saavedra, M.J.; Rosa, E.A.S.; Bennett, R.N. The antimicrobial effects of glucosinolates and their respective enzymatic hydrolysis products on bacteria isolated from the human intestinal tract. J. Appl. Microbiol. 2009, 106, $2086-2095$. [CrossRef] [PubMed]

17. Drobnica, L.; Zemanová, M.; Nemec, P.; Antos, K.; Kristián, P.; Stullerová, A.; Knoppová, V.; Nemec, P. Antifungal activity of isothiocyanates and related compounds. I. Naturally occurring isothiocyanates and their analogues. Appl. Microbiol. 1967, 15, 701-709. [CrossRef]

18. Fahey, J.W.; Zhang, Y.; Talalay, P. Broccoli sprouts: An exceptionally rich source of inducers of enzymes that protect against chemical carcinogens. Proc. Natl. Acad. Sci. USA 1997, 94, 10367-10372. [CrossRef]

19. Coscueta, E.R.; Reis, C.A.; Pintado, M. Phenylethyl isothiocyanate extracted from watercress by-products with aqueous micellar systems: Development and optimisation. Antioxidants 2020, 9, 698. [CrossRef]

20. Palliyaguru, D.L.; Yuan, J.-M.; Kensler, T.W.; Fahey, J.W. Isothiocyanates: Translating the Power of Plants to People. Mol. Nutr. Food Res. 2018, 62, 1700965. [CrossRef]

21. Nowicki, D.; Maciag-Dorszyńska, M.; Bogucka, K.; Szalewska-Pałasz, A.; Herman-Antosiewicz, A. Various modes of action of dietary phytochemicals, sulforaphane and phenethyl isothiocyanate, on pathogenic bacteria. Sci. Rep. 2019, 9, 1-12. [CrossRef]

22. Nowicki, D.; Maciag-Dorszyńska, M.; Kobiela, W.; Herman-Antosiewicz, A.; Wȩgrzyn, A.; Szalewska-Pałasz, A.; Wȩgrzyn, G. Phenethyl isothiocyanate inhibits Shiga toxin production in enterohemorrhagic Escherichia coli by stringent response induction. Antimicrob. Agents Chemother. 2014, 58, 2304-2315. [CrossRef]

23. Kaiser, S.J.; Mutters, N.T.; Blessing, B.; Günther, F. Natural isothiocyanates express antimicrobial activity against developing and mature biofilms of Pseudomonas aeruginosa. Fitoterapia 2017, 119, 57-63. [CrossRef]

24. Romeo, L.; Iori, R.; Rollin, P.; Bramanti, P.; Mazzon, E. Isothiocyanates: An Overview of Their Antimicrobial Activity against Human Infections. Molecules 2018, 23, 624. [CrossRef]

25. Nowicki, D.; Rodzik, O.; Herman-Antosiewicz, A.; Szalewska-Pałasz, A. Isothiocyanates as effective agents against enterohemorrhagic Escherichia coli: Insight to the mode of action. Sci. Rep. 2016, 6, 1-12. [CrossRef] 
26. Barlow, G. Clinical challenges in antimicrobial resistance. Nat. Microbiol. 2018. [CrossRef]

27. Kolter, R.; Van Wezel, G.P. Goodbye to brute force in antibiotic discovery? Nat. Microbiol. 2016, 1, 1-2. [CrossRef]

28. Jang, M.; Hong, E.; Kim, G.-H. Evaluation of antibacterial activity of 3-butenyl, 4-pentenyl, 2-phenylethyl, and benzyl isothiocyanate in Brassica vegetables. J. Food Sci. 2010, 75, M412-M416. [CrossRef]

29. Aires, A.; Mota, V.R.; Saavedra, M.J.; Monteiro, A.A.; Simões, M.; Rosa, E.A.S.; Bennett, R.N. Initial in vitro evaluations of the antibacterial activities of glucosinolate enzymatic hydrolysis products against plant pathogenic bacteria. J. Appl. Microbiol. 2009, 106, 2096-2105. [CrossRef]

30. Dufour, V.; Alazzam, B.; Thepaut, M.; Ermel, G.; Baysse, C. Antimicrobial Activities of Isothiocyanates Against Campylobacter jejuni Isolates. Front. Cell. Infect. Microbiol. 2012, 2, 53. [CrossRef]

31. Borges, A.; Abreu, A.C.; Ferreira, C.; Saavedra, M.J.; Simões, L.C.; Simões, M. Antibacterial activity and mode of action of selected glucosinolate hydrolysis products against bacterial pathogens. J. Food Sci. Technol. 2015, 52, 4737-4748. [CrossRef] [PubMed]

32. Sánchez-Pujante, P.J.; Borja-Martínez, M.; Pedreño, M.Á.; Almagro, L. Biosynthesis and bioactivity of glucosinolates and their production in plant in vitro cultures. Planta 2017, 246, 19-32. [CrossRef] [PubMed]

33. Melrose, J. The Glucosinolates: A Sulphur Glucoside Family of Mustard Anti-Tumour and Antimicrobial Phytochemicals of Potential Therapeutic Application. Biomedicines 2019, 7, 62. [CrossRef] [PubMed]

34. Niu, T.-X.; Wang, X.-N.; Wu, H.-Y.; Bi, J.-R.; Hao, H.-S.; Hou, H.-M.; Zhang, G.-L. Transcriptomic Analysis, Motility and Biofilm Formation Characteristics of Salmonella typhimurium Exposed to Benzyl Isothiocyanate Treatment. Int. J. Mol. Sci. 2020, 21, 1025. [CrossRef]

35. Borges, A.; Simoes, L.C.; Saavedra, M.J.; Simoes, M. The action of selected isothiocyanates on bacterial biofilm prevention and control. Int. Biodeterior. Biodegrad. 2014, 86, 25-33. [CrossRef]

36. Jakobsen, T.H.; Bragason, S.K.; Phipps, R.K.; Christensen, L.D.; van Gennip, M.; Alhede, M.; Skindersoe, M.; Larsen, T.O.; Høiby, N.; Bjarnsholt, T.; et al. Food as a source for quorum sensing inhibitors: Iberin from horseradish revealed as a quorum sensing inhibitor of Pseudomonas aeruginosa. Appl. Environ. Microbiol. 2012, 78, 2410-2421. [CrossRef]

37. Hyldgaard, M.; Mygind, T.; Meyer, R.L.; Hayashi, M.A.F.; Knapp, C. Essential oils in food preservation: Mode of action, synergies, and interactions with food matrix components. Front. Microbiol. 2012, 3, 12. [CrossRef]

38. Muscolino, D.; Giarratana, F.; Beninati, C.; Ziino, G.; Giuffrida, A.; Panebianco, A. Effects of allyl isothiocyanate on the shelf-life of gilthead sea bream (Sparus aurata) fillets. Czech J. Food Sci. 2016, 34, 160-165. [CrossRef]

39. Saleh, N.M.; Mabrouk, M.I.; Salem-Bekhit, M.M.; Hafez, E.H.; Salem-Bekhit, M. Challenge of Moringa peregrina Forssk as an antimicrobial agent against multi-drug-resistant Salmonella sp. Biotechnol. Biotechnol. Equip. 2016, 21, 380-386. [CrossRef]

40. Shi, H.; Westfall, C.S.; Kao, J.; Odermatt, P.D.; Anderson, S.E.; Cesar, S.; Sievert, M.; Moore, J.; Gonzalez, C.G.; Zhang, L.; et al. Starvation induces shrinkage of the bacterial cytoplasm. Proc. Natl. Acad. Sci. USA 2021, 118, e2104686118. [CrossRef]

41. Brooks, A.; Yau, J.; Pham, S. Stringent Response Changes Cell Membrane Permeability in Escherichia coli but does not Develop Cross Tolerance to Kanamycin, Tetracycline and Ampicillin. J. Exp. Microbiol. Immunol. 2011, 15, 30-35.

42. Gitter, B.; Diefenbach, R.; Keweloh, H.; Riesenberg, D. Influence of stringent and relaxed response on excretion of recombinant proteins and fatty acid composition in Escherichia coli. Appl. Microbiol. Biotechnol. 1995, 43, 89-92. [CrossRef]

43. Potrykus, K.; Cashel, M. (p)ppGpp: Still magical? Annu. Rev. Microbiol. 2008, 62, 35-51. [CrossRef]

44. Dennis, P.P.; Ehrenberg, M.; Bremer, H. Control of rRNA synthesis in Escherichia coli: A systems biology approach. Microbiol. Mol. Biol. Rev. 2004, 68, 639-668. [CrossRef]

45. Nowicki, D.; Krause, K.; Szamborska, P.; Żukowska, A.; Cech, G.M.; Szalewska-Pałasz, A. Induction of the Stringent Response Underlies the Antimicrobial Action of Aliphatic Isothiocyanates. Front. Microbiol. 2021, 11, 1-14. [CrossRef]

46. Karlsson, I.; Samuelsson, K.; Ponting, D.J.; Törnqvist, M.; Ilag, L.L.; Nilsson, U. Peptide Reactivity of Isothiocyanates-Implications for Skin Allergy. Sci. Rep. 2016, 6, 21203. [CrossRef]

47. Cejpek, K.; Valusek, J.; Velísek, J. Reactions of allyl isothiocyanate with alanine, glycine, and several peptides in model systems. J. Agric. Food Chem. 2000, 48, 3560-3565. [CrossRef]

48. Lin, C.M.; Preston, J.F., 3rd; Wei, C.I. Antibacterial mechanism of allyl isothiocyanate. J. Food Prot. 2000, 63, 727-734. [CrossRef]

49. Luciano, F.B.; Holley, R.A. Enzymatic inhibition by allyl isothiocyanate and factors affecting its antimicrobial action against Escherichia coli O157:H7. Int. J. Food Microbiol. 2009, 131, 240-245. [CrossRef]

50. Bina, J.; Zhu, J.; Dziejman, M.; Faruque, S.; Calderwood, S.; Mekalanos, J. ToxR regulon of Vibrio cholerae and its expression in vibrios shed by cholera patients. Proc. Natl. Acad. Sci. USA 2003, 100, 2801-2806. [CrossRef]

51. Silva, A.J.; Benitez, J.A. A Vibrio cholerae relaxed (relA) mutant expresses major virulence factors, exhibits biofilm formation and motility, and colonizes the suckling mouse intestine. J. Bacteriol. 2006, 188, 794-800. [CrossRef] [PubMed]

52. Fernández-Coll, L.; Cashel, M. Possible Roles for Basal Levels of (p)ppGpp: Growth Efficiency Vs. Surviving Stress. Front. Microbiol. 2020, 11, 592718. [CrossRef] [PubMed]

53. Yamamoto, K.; Nagano, T.; Kumagai, H.; Okamoto, Y.; Otani, S. Destruction of cholera toxin receptor on HeLa cell membrane using microbial endoglycoceramidase. Arch. Biochem. Biophys. 1996, 328, 51-56. [CrossRef] [PubMed]

54. Tugba Artun, F.; Karagoz, A.; Ozcan, G.; Melikoglu, G.; Anil, S.; Kultur, S.; Sutlupinar, N. In vitro anticancer and cytotoxic activities of some plant extracts on HeLa and Vero cell lines. JBUON 2016, 21, 720-725.

55. Majoul, I.; Schmidt, T.; Pomasanova, M.; Boutkevich, E.; Kozlov, Y.; Söling, H.-D. Differential expression of receptors for Shiga and Cholera toxin is regulated by the cell cycle. J. Cell Sci. 2002, 115, 817-826. [CrossRef] 
56. Samuel, J.E.; Perera, L.P.; Ward, S.; Brien, A.D.O.; Ginsburg, V.; Krivan, H.C.; Al, S.E.T. Comparison of the Glycolipid Receptor Specificities of Shiga-Like Toxin Type II and Shiga-Like Toxin Type II Variants. Infect. Immunol. 1990, 58, 611-618. [CrossRef]

57. Bokhari, H.; Ali, A.; Noreen, Z.; Thomson, N.; Wren, B.W. Galleria mellonella is low cost and suitable surrogate host for studying virulence of human pathogenic Vibrio cholerae. Gene 2017, 628, 1-7. [CrossRef]

58. Nuidate, T.; Tansila, N.; Saengkerdsub, S.; Kongreung, J.; Bakkiyaraj, D.; Vuddhakul, V. Role of Indole Production on Virulence of Vibrio cholerae Using Galleria mellonella Larvae Model. Indian J. Microbiol. 2016, 56, 368-374. [CrossRef]

59. Schepici, G.; Bramanti, P.; Mazzon, E. Efficacy of Sulforaphane in Neurodegenerative Diseases. Int. J. Mol. Sci. 2020, 21, 8637. [CrossRef]

60. Ambrecht, L.A.; Perlman, J.I.; McDonnell, J.F.; Zhai, Y.; Qiao, L.; Bu, P. Protection of retinal function by sulforaphane following retinal ischemic injury. Exp. Eye Res. 2015, 138, 66-69. [CrossRef]

61. Kaushik, J.S.; Gupta, P.; Faridi, M.M.; Das, S. Single dose azithromycin versus ciprofloxacin for cholera in children: A randomized controlled trial. Indian Pediatr. 2010, 47, 309-315. [CrossRef]

62. Mahn, A.; Castillo, A. Potential of Sulforaphane as a Natural Immune System Enhancer: A Review. Molecules 2021, 26, 752. [CrossRef]

63. Ali, M.; Bonay, M.; Vanhee, V.; Vinit, S.; Deramaudt, T.B. Comparative effectiveness of 4 natural and chemical activators of Nrf2 on inflammation, oxidative stress, macrophage polarization, and bactericidal activity in an in vitro macrophage infection model. PLoS ONE 2020, 15, e0234484. [CrossRef]

64. Deramaudt, T.B.; Ali, M.; Vinit, S.; Bonay, M. Sulforaphane reduces intracellular survival of Staphylococcus aureus in macrophages through inhibition of JNK and p38 MAPK-induced inflammation. Int. J. Mol. Med. 2020, 45, 1927-1941. [CrossRef]

65. Wojda, I.; Koperwas, K.; Jakubowicz, T. Activation of MAP kinase pathways in Galleria mellonella infected with Bacillus thuringiensis. Acta Biochim. Pol. 2014, 61, 185-189. [CrossRef]

66. Grizanova, E.V.; Dubovskiy, I.M.; Whitten, M.M.A.; Glupov, V. V Contributions of cellular and humoral immunity of Galleria mellonella larvae in defence against oral infection by Bacillus thuringiensis. J. Invertebr. Pathol. 2014, 119, 40-46. [CrossRef]

67. Häse, C.C.; Mekalanos, J.J. TcpP protein is a positive regulator of virulence gene expression in Vibrio cholerae. Proc. Natl. Acad. Sci. USA 1998, 95, 730-734. [CrossRef]

68. Häse, C.C.; Mekalanos, J.J. Effects of changes in membrane sodium flux on virulence gene expression in Vibrio cholerae. Proc. Natl. Acad. Sci. USA 1999, 96, 3183-3187. [CrossRef]

69. Andrews, J.M. Determination of minimum inhibitory concentrations. J. Antimicrob. Chemother. 2001, 48 (Suppl. 1), 5-16. [CrossRef]

70. Zhou, X.-Y.; Ye, X.-G.; He, L.-T.; Zhang, S.-R.; Wang, R.-L.; Zhou, J.; He, Z.-S. In vitro characterization and inhibition of the interaction between ciprofloxacin and berberine against multidrug-resistant Klebsiella pneumoniae. J. Antibiot. 2016, 69, 741-746. [CrossRef]

71. Nejman-Faleńczyk, B.; Bloch, S.; Januszkiewicz, A.; Węgrzyn, A.; Wẹgrzyn, G. A simple and rapid procedure for the detection of genes encoding shiga toxins and other specific DNA sequences. Toxins 2015, 7, 4745-4757. [CrossRef]

72. Mechold, U.; Potrykus, K.; Murphy, H.; Murakami, K.S.; Cashel, M. Differential regulation by ppGpp versus pppGpp in Escherichia coli. Nucleic Acids Res. 2013, 41, 6175-6189. [CrossRef]

73. Wu, G.; Liu, Y.; Ding, Y.; Yi, Y. Ultrastructural and functional characterization of circulating hemocytes from Galleria mellonella larva: Cell types and their role in the innate immunity. Tissue Cell 2016, 48, 297-304. [CrossRef] [PubMed] 